\title{
Interleukin 18 Measurement
}

National Cancer Institute

\section{Source}

National Cancer Institute. Interleukin 18 Measurement. NCI Thesaurus. Code C74814.

The determination of the amount of interleukin 18 present in a sample. 